\title{
Pendugaan Ragam Genetik dan Heritabilitas Karakter Agronomi Gandum (Triticum aestivum L.) Hasil Berbagai Perlakuan Teknik Iradiasi Sinar Gamma
}

\section{Estimation of Genetic Variability and Heritability of Wheat Agronomic Traits Resulted from Some Gamma Rays Irradiation Techniques}

\author{
Wijaya Murti Indriatama ${ }^{1}$, Trikoesoemaningtyas ${ }^{1}$, Syarifah Iis Aisyah ${ }^{1}$ dan \\ Soeranto Human ${ }^{2}$ \\ ${ }^{1}$ Departemen Agronomi dan Hortikultura, Institut Pertanian Bogor \\ Jl. Meranti, IPB Dramaga Campus Bogor - Indonesia 16680 \\ ${ }^{2}$ Pusat Aplikasi Isotop dan Radiasi, BATAN \\ Jl. Lebak Bulus Raya No. 49 Jakarta 12440 \\ E-mail : trikadytia@gmail.com
}

Diterima 29-06-2016; Diterima dengan revisi 22-08-2016; Disetujui 19-10-2016

\begin{abstract}
ABSTRAK
Teknik iradiasi sinar gamma dapat meningkatkan frekuensi dan memperluas spektrum mutasi makro namun belum banyak dikaji pengaruhnya terhadap mutasi mikro pada karakter kuantitatif dalam populasi termutasi. Penelitian ini bertujuan untuk mempelajari pengaruh perlakuan teknik iradiasi terhadap keragaman genetik dan heritabilitas karakter agronomi gandum pada generasi M2. Penelitian ini dilaksanakan dari bulan Juli sampai November 2014 di kebun percobaan Cibadak, Balai Besar Penelitian dan Pengembangan Bioteknologi dan Sumber Daya Genetik Pertanian, Kementerian Pertanian. Benih tiga galur gandum (F-44, K-95 dan WL-711) diberikan perlakuan tiga teknik iradiasi sinar gamma (akut, terbagi dan berulang). Generasi M1 ditanam secara bulk di lahan dan dipanen secara individu. Sebanyak 75 malai tiap kombinasi perlakuan ditanam satu baris per malai sebagai generasi M2 dan diamati karakter agronominya. Perlakuan teknik iradiasi sinar gamma menginduksi perluasan nilai kisaran semua karakter agronomi populasi M2. Teknik iradiasi terbagi mampu menginduksi nilai rataan yang lebih tinggi dengan kisaran yang lebih luas pada karakter panjang malai dan jumlah spikelet per malai dibanding teknik iradiasi yang lain. Teknik iradiasi terbagi dan berulang menghasilkan ragam yang lebih besar dibanding iradiasi akut pada karakter hasil biji per tanaman. Karakter agronomi jumlah anakan produktif, bobot malai, bobot biji per malai dan bobot biji per tanaman pada populasi M2 hasil induksi tiga teknik iradiasi memiliki heritabilitas yang tinggi. Tiga teknik iradiasi menginduksi perluasan keragaman genetik semua karakter agronomi populasi M2 yang diamati, kecuali tinggi tanaman.
\end{abstract}

Kata Kunci : iradiasi akut, iradiasi terbagi, iradiasi berulang, mutasi mikro.

\begin{abstract}
Gamma irradiation techniques have significant effect on frequency and spectrum of macromutation but the study of its effect on micro-mutation that related to genetic variability on mutated population is very limited. The aim of this research was to study the effect of gamma irradiation techniques on genetic variability and heritability of wheat agronomic characters at M2 generation. This research was conducted from July to November 2014, at Cibadak experimental station, Indonesian Center for Agricultural Biotechnology and Genetic Resources Research and Development, Ministry of Agriculture. Three introduced wheat breeding lines (F-44, Kiran-95 \& WL-711) were treated by 3 gamma irradiation techniques (acute, fractionated and intermittent). M1 generation of combination treatments were planted and harvested its spike individually per plants. As M2 generation, seeds of $75 \mathrm{M} 1$ spike were planted at the field with one row one spike method and evaluated on the agronomic characters and its genetic components. The used of gamma irradiation techniques decreased mean but increased range values of agronomic traits in M2 populations. Fractionated irradiation induced higher mean and wider range on spike length and number of spikelet per spike than other irradiation techniques. Fractionated and intermittent irradiation resulted greater variability of grain weight per plant than acute irradiation. The number of tillers, spike weight, grain weight per spike and grain weight per plant on M2 population resulted from induction of three gamma irradiation techniques have high estimated heritability and broad
\end{abstract}


sense of genetic variability coefficient values. The three gamma irradiation techniques increased genetic variability of agronomic traits on M2 populations, except plant height.

Keywords : acute irradiation, fractionated irradiation, intermittent irradiation, micro-mutation.

\section{PENDAHULUAN}

Kebutuhan gandum Indonesia terus meningkat sehingga penelitian dan pengembangan gandum dalam negeri mendesak untuk dilakukan [1]. Namun gandum merupakan tanaman yang berasal dari wilayah subtropis memerlukan suhu tumbuh rendah sekitar $22-24^{\circ} \mathrm{C}$ sehingga pengembangannya masih terbatas pada lingkungan dataran tinggi. Pemulia gandum Indonesia berusaha untuk mengadaptasikan gandum pada lingkungan yang lebih rendah melalui perakitan varietas baru dengan berbagai metode baik introduksi, persilangan, maupun mutasi [2].

Mutasi induksi menjadi salah satu metode yang banyak dipilih dalam pemuliaan gandum. Induksi mutasi pada bahan genetik dapat dilakukan dengan menggunakan mutagen fisik seperti sinar gamma Sinar gamma mampu menembus permukaan dan menimbulkan perubahan morfologi, sitologi, dan fisiologi dalam sel maupun jaringan tanaman [3]. Mutasi menjadi salah satu faktor yang menyebabkan perubahan ekspresi gen sehingga meningkatkan keragaman genetik di dalam populasi [4]. Keragaman karakter yang muncul akibat induksi mutasi mempermudah pemulia dalam melaksanakan seleksi sesuai tujuan pemuliaannya [5].

Perakitan varietas gandum adaptif iklim tropis menggunakan induksi mutasi sinar gamma telah dilakukan para peneliti di PAIR-BATAN dan telah menghasilkan satu varietas gandum untuk dataran tinggi yaitu Ganesha. Penelitian dilanjutkan dengan program perakitan varietas gandum adaptif dataran rendah yang diawali dengan mengeskplorasi teknik iradiasi dalam rangka meningkatkan ragam populasi. Tingginya ragam populasi yang didapat akan memperbesar peluang untuk mendapatkan galur mutan yang tahan suhu tinggi dan adaptif tumbuh di dataran rendah.

Penggunaan teknik iradiasi sinar gamma yang tepat dapat meningkatkan frekuensi dan spektrum mutasi [6] dan menurunkan efek negatif kerusakan fisiologi akibat iradiasi [7]. Penelitian induksi mutasi yang telah dilakukan umumnya menggunakan teknik iradiasi akut. Teknik ini dipercaya dapat menghasilkan keragaman lebih besar dibanding teknik iradiasi yang lain [8]. Hasil penelitian Banerjee menunjukkan bahwa perlakuan iradiasi terbagi menginduksi ragam tertinggi pada generasi M2 gandum [9] sedangkan perlakuan iradiasi berulang pada penelitian Aisyah mampu memperluas spektrum mutasi pada Anyelir [10]. Hasil penelitian tersebut menunjukkan bahwa teknik iradiasi yang diaplikasikan berpengaruh terhadap peningkatan ragam populasi, frekuensi maupun spektrum mutasi. Penelitian ini bertujuan untuk mempelajari pengaruh perlakuan 3 teknik iradiasi terhadap keragaman genetik dan heritabilitas karakter agronomi gandum pada generasi M2.

\section{BAHAN DAN METODE}

Penelitian dilaksanakan pada bulan Juli sampai bulan November 2014 di kebun percobaan Cibadak, Balai Besar Penelitian dan Pengembangan Bioteknologi dan Sumber Daya Genetik Pertanian, Cipanas dengan ketinggian 900 m dpl.

Materi genetik yang digunakan dalam penelitian ini adalah benih generasi M2 (hasil panen dari penanaman M1 asal galur F-44, K-95 dan WL-711 yang diradiasi sinar gamma secara akut, terbagi dan berulang). Perlakuan iradiasi akut (acute) dilakukan dengan meradiasi benih sekali dengan dosis tunggal (250 Gy). Perlakuan iradiasi terbagi (fractionated) diaplikasikan dengan meradiasi dua kali, masing-masing setengah dari dosis iradiasi akut $(125+125 \mathrm{~Gy})$. Perlakuan iradiasi berulang (intermittent) dilaksanakan dengan meradiasi benih dua kali, dimana dosis iradiasi yang kedua setengah dari perlakuan dosis iradiasi awal dengan interval waktu 24 jam (125+65 Gy).

Sebanyak 75 malai generasi M1 diambil dari tiap kombinasi perlakuan galur dan teknik iradiasi. Tiap malai gandum terpilih diambil masing-masing 20 biji, dipilih yang bernas, tidak berjamur dan tidak berkecambah (sprouting). Setiap malai ditanam satu baris pada bedengan 
lebar $1 \mathrm{~m}$ dengan jarak $5 \mathrm{~cm}$ antar biji dalam baris dan $30 \mathrm{~cm}$ antar baris. Tiap 25 baris ditanam satu baris tanaman induk sebagai kontrol (galur F-44, K-95 dan WL-711). Pemupukan diberikan dua kali yaitu pada saat tanaman berumur 10 HST dengan dosis $150 \mathrm{~kg} \cdot \mathrm{ha}^{-1}$ Urea, $200 \mathrm{~kg} \cdot \mathrm{ha}^{-1} \mathrm{SP} 36$ dan $\mathrm{KCl} 100 \mathrm{~kg} \cdot \mathrm{ha}^{-1}$ dan pemupukan kedua dengan dosis Urea $150 \mathrm{~kg} \cdot \mathrm{ha}^{-1}$ pada umur $30 \mathrm{HST}$. Semua tanaman yang hidup diambil dari tiap kombinasi perlakuan galur dan teknik iradiasi untuk diamati karakter agronominya. Pengamatan dilakukan pada karakter tinggi tanaman $(\mathrm{cm})$, jumlah anakan produktif, panjang malai $(\mathrm{cm})$, jumlah spikelet tiap malai, bobot malai (g), jumlah biji tiap malai, bobot biji tiap malai $(\mathrm{g})$ dan bobot biji per tanaman $(\mathrm{g})$.

Analisis data diawali dengan menghitung rataan setiap karakter kuantitatif dari masingmasing populasi M2 hasil induksi tiga teknik iradiasi sinar gamma pada tiga galur gandum introduksi, kemudian rataan masing-masing populasi tersebut diuji menggunakan uji $\mathrm{t}$ dibandingkan dengan rataan galur asal.

Untuk melihat variabilitas dalam masingmasing populasi M2 digunakan pendugaan nilai ragam. Nilai ragam yang diperoleh dari semua variabel pengamatan pada populasi M2 digunakan dalam uji homogenitas ragam. Pengujian homogenitas ragam dimaksudkan untuk membandingkan nilai ragam antar dua populasi M2 hasil induksi tiga teknik iradiasi dengan menggunakan uji $\mathrm{F}$.

Analisis ragam dilanjutkan dengan pendugaan ragam lingkungan menggunakan ragam karakter kuantitatif induk. Ragam fenotipik diambil dari ragam populasi M2 pada masing-masing perlakuan galur dan teknik iradiasi. Ragam genotip diduga dengan menyelisihkan ragam fenotip pada populasi M2 masing-masing kombinasi perlakuan dengan ragam galur induk. Nilai heritabilitas dihitung dengan menggunakan rumus [11]:

$$
h^{2}=\sigma^{2} g / \sigma^{2} p
$$

Kriteria nilai heritabilitas yaitu tinggi $\left(\mathrm{h}^{2}>0,5\right)$, sedang $\left(0,2 \leq h^{2} \leq 0,5\right)$ dan rendah $\left(h^{2}<0,2\right)$.

Variasi genetik ditentukan berdasarkan pada koefisien keragaman genetik (KKG) menggunakan metode sebagai berikut [11]:
Nilai koefisien keragaman genetik (KKG):

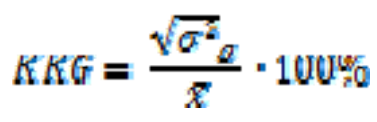

dimana $: \bar{X}=$ rata-rata nilai sifat

Penentuan luas sempitnya keragaman genetik ditentukan menggunakan kriteria sebagai berikut: apabila $\sigma_{\mathrm{g}}^{2}>2 \sigma_{\sigma 2 \mathrm{~g}}$ maka keragaman genetiknya luas, sedangkan jika $\sigma_{g}^{2}>2 \sigma_{\sigma 2 g}$ maka keragaman genetiknya sempit [12].

\section{HASIL DAN PEMBAHASAN}

Keberhasilan induksi mutasi pada karakter poligenik dapat dilihat dari pendugaan rataan, kisaran, koefisien keragaman dan heritabilitas dalam populasi M2 pasca perlakuan mutagen [13]. Dalam penelitian ini, parameter rataan dan komponen genetik lainnya diduga melalui pengamatan karakter agronomi gandum pada masing-masing populasi M2. Keragaan populasi mutan gandum generasi M2 hasil perlakuan teknik iradiasi gamma dapat dilihat pada Tabel 1 .

Perlakuan iradiasi baik akut, terbagi dan berulang menginduksi penurunan rerata karakter tinggi tanaman, jumlah spikelet per malai, bobot malai, jumlah biji per malai, dan bobot biji per malai pada tiga galur yang digunakan.Hal yang sama juga terjadi pada penelitian Sakin, iradiasi sinar gamma pada dosis 250 Gy menurunkan rataan karakter kuantitatif gandum generasi M2 [14]. Penurunan rerata karakter kuantitatif pada generasi M2 akibat iradiasi diawali oleh besarnya mutasi DNA pada generasi M1 kemudian gen-gen yang termutasi bersegregasi dan menimbulkan ekspresi negatif pada generasi M2. Kerusakan yang bersifat tidak balik (irreversible) pada susunan DNA gen-gen mayor pengendali karakter kuantitatif pada saat iradiasi akan berdampak pada penurunan karakter tersebut pada generasi bersegregasi [15]. Efek random mutasi radiasi memicu munculnya ekspresi gen yang bersifat negatif seperti lethalitas, sterilitas pada baik total maupun parsial serta abnormalitas bentuk pada karakter komponen hasil tanaman $[16,17]$. Efek negatif tersebut berpotensi menyebabkan rerata komponen hasil pada generasi M2 lebih rendah dari kontrol. 
Tiga perlakuan iradiasi menginduksi penurunan rerata karakter jumlah anakan produktif, panjang malai, bobot biji per tanaman pada galur F-44. Namun pada galur K-95 dan WL711, perlakuan iradiasi tersebut menginduksi rerata karakter jumlah anakan produktif dan bobot biji per malai yang sama atau lebih baik dari kontrol. Hal ini menunjukkan terdapat variasi tanggapan tiap galur terhadap iradiasi yang diaplikasikan. Setiap jenis tanaman memiliki radiosensitivitas berbeda [18]. Demikian pula galur berbeda dalam jenis yang sama, terdapat kemungkinan perbedaan sensitivitas terhadap iradiasi sinar gamma. Penelitian [19] pada gandum sintetik yang diradiasi menggunakan sinar gamma dengan dosis yang sama menghasilkan respon yang berbeda pada tiap galurnya. Terdapat galur mutan gandum sintetik tertentu yang lebih sensitif terhadap iradiasi. Penurunan rerata karakter jumlah anakan produktif dan bobot biji per malai menunjukkan bahwa galur F-44 lebih sensitif terhadap perlakuan iradiasi dibandingkan dengan galur K-95 dan WL-711.

Nilai rerata karakter panjang malai dan jumlah spikelet hasil induksi iradiasi terbagi pada galur F-44 dan WL-711 lebih tinggi dari teknik iradiasi lain dan tidak berbeda nyata dengan kontrol. Hal ini menunjukkan bahwa pengaruh induksi iradiasi terbagi pada komponen hasil generasi M2 lebih baik dibanding dengan iradiasi

Tabel 1. Rataan, standar deviasi dan kisaran karakter tinggi tanaman (cm), jumlah anakan produktif, panjang malai, jumlah spikelet per malai bobot malai, jumlah biji per malai, bobot biji per malai dan bobot biji per tanaman gandum generasi M2

\begin{tabular}{|c|c|c|c|c|c|c|c|c|}
\hline \multirow[t]{2}{*}{ Perlakuan } & \multicolumn{2}{|c|}{ Tinggi tanaman $(\mathrm{cm})$} & \multicolumn{2}{|c|}{$\begin{array}{c}\text { Jumlah Anakan } \\
\text { Produktif }\end{array}$} & \multicolumn{2}{|c|}{ Panjang malai $(\mathrm{cm})$} & \multicolumn{2}{|c|}{ Jumlah spikelet per malai } \\
\hline & $\mathrm{X} \pm \mathrm{Sx}$ & Kisaran & $\mathrm{X} \pm \mathrm{Sx}$ & Kisaran & $\mathrm{X} \pm \mathrm{Sx}$ & Kisaran & $\mathrm{X} \pm \mathrm{Sx}$ & Kisaran \\
\hline \multicolumn{5}{|l|}{ Kontrol } & $7,3 \pm 0,8$ & $6-8,5$ & $15,1 \pm 2,0$ & $11-18,0$ \\
\hline K-95 & $51,8 \pm 8,9$ & $42-69$ & $5,2 \pm 1,9$ & $3-8$ & $6,8 \pm 1,0$ & $5-8,0$ & $15 \pm 1,5$ & $12-17,0$ \\
\hline WL-711 & $69 \pm 6,2$ & $55-76$ & $5,4 \pm 1,7$ & $3-8$ & $8,9 \pm 0,7$ & $8-10,0$ & $15,4 \pm 0,9$ & $14-17,0$ \\
\hline \multicolumn{9}{|l|}{ Akut } \\
\hline $\mathrm{F}-44$ & $42,5^{*} \pm 7,3$ & $24-60$ & $2,7^{* *} \pm 1,5$ & $1-9$ & $6,6^{*} \pm 1,2$ & $4-10,0$ & $13,6^{*} \pm 2,8$ & $8-22,0$ \\
\hline K-95 & $46,4^{* *} \pm 9,0$ & $26-62$ & $4,9 \pm 3,5$ & $1-16$ & $7,1 \pm 1,3$ & $3-11,0$ & $14,9 \pm 2,7$ & $6-21,0$ \\
\hline WL-711 & $56,2^{* *} \pm 8,7$ & $29-79$ & $7,4^{* *} \pm 4$ & $1-20$ & $8,1^{* *} \pm 1,1$ & $6-11,0$ & $13,4^{* *} \pm 2,4$ & $8-21,0$ \\
\hline \multicolumn{9}{|l|}{ Terbagi } \\
\hline F-44 & $45,6 \pm 6,9$ & $19-60$ & $3,3^{* *} \pm 2,1$ & $1-12$ & $7,2 \pm 1,2$ & $2-10,0$ & $15,4 \pm 2,2$ & $11-21,0$ \\
\hline K-95 & $47,9^{* *} \pm 10$ & $24-65$ & $4,7 \pm 3,2$ & $1-16$ & $7,1 \pm 1,5$ & $2-10,0$ & $13,9^{*} \pm 3,1$ & $6-20,0$ \\
\hline WL-711 & $60,6^{* *} \pm 10,4$ & $26-81$ & $7,8^{* *} \pm 5$ & $1-23$ & $8,7 \pm 1,6$ & $3-12,0$ & $15,2 \pm 2,2$ & $7-20,0$ \\
\hline \multicolumn{9}{|l|}{ Berulang } \\
\hline F-44 & $43,8^{*} \pm 6,1$ & $27-59$ & $3,5^{* *} \pm 1,9$ & $1-12$ & $6,8^{*} \pm 0,9$ & $4-9,0$ & $13,9^{*} \pm 2,4$ & $10-20,0$ \\
\hline K-95 & $56,9 \pm 8,2$ & $33-74$ & $6,1^{*} \pm 4,3$ & $1-25$ & $7,7^{*} \pm 1,3$ & $5-11,0$ & $15,1 \pm 2,8$ & $8-21,0$ \\
\hline \multirow[t]{2}{*}{ WL-711 } & $56,2^{* *} \pm 9,0$ & $35-74$ & $5,7 \pm 3,2$ & $1-16$ & $7,8^{* *} \pm 1,2$ & $5-10,0$ & $14,2^{* *} \pm 2,4$ & $8-20,0$ \\
\hline & \multicolumn{2}{|c|}{ Bobot malai $(\mathrm{g})$} & \multicolumn{2}{|c|}{ Jumlah biji per malai } & \multicolumn{2}{|c|}{ Bobot biji per malai $(g)$} & \multicolumn{2}{|c|}{ Bobot biji per tanaman $(g)$} \\
\hline \multicolumn{9}{|l|}{ Kontrol } \\
\hline K-95 & $2,27 \pm 0,36$ & $1,42-2,38$ & $45,9 \pm 8,2$ & $29-54$ & $1,49 \pm 0,3$ & $0,64-1,64$ & $4,43 \pm 1,6$ & $1,6-6,95$ \\
\hline WL-711 & $2,67 \pm 0,3$ & $2,13-3,11$ & $50,6 \pm 6,5$ & $36-61$ & $1,9 \pm 0,26$ & $1,4-2,18$ & $5,68 \pm 1,13$ & $3,8-7,05$ \\
\hline \multicolumn{9}{|l|}{ Akut } \\
\hline $\mathrm{F}-44$ & $1,49^{* *} \pm 0,61$ & $0,24-3,25$ & $29,2^{* *} \pm 13,1$ & $3,0-62$ & $0,87^{* *} \pm 0,54$ & $0,05-2,5$ & $1,97^{* *} \pm 1,47$ & $0,1-6,63$ \\
\hline K-95 & $1,94^{* *} \pm 0,67$ & $0,49-3,22$ & $38,2^{* *} \pm 14,8$ & $6,0-74$ & $1,23^{* *} \pm 0,53$ & $0,18-2,36$ & $4,61 \pm 3,95$ & $0,2-17,33$ \\
\hline WL-711 & $1,89^{* *} \pm 0,61$ & $0,69-4,41$ & $39,1^{* *} \pm 11,9$ & $13-86$ & $1,29^{* *} \pm 0,53$ & $0,17-3,29$ & $6,2 \pm 4,47$ & $0,2-19,18$ \\
\hline \multicolumn{9}{|l|}{ Terbagi } \\
\hline F-44 & $2,00 \pm 0,69$ & $0,28-4,08$ & $41,1 \pm 11,2$ & $9,0-78$ & $1,25^{*} \pm 0,56$ & $0,19-2,68$ & $3,35^{* *} \pm 2,11$ & $0,4-9,51$ \\
\hline K-95 & $1,82^{* *} \pm 0,74$ & $0,54-3,52$ & $36,7^{* *} \pm 15,8$ & $5,0-73$ & $1,12^{* *} \pm 0,62$ & $0,16-2,63$ & $4,31 \pm 4,57$ & $0,2-21,99$ \\
\hline WL-711 & $2,16^{* *} \pm 0,67$ & $0,53-3,63$ & $41,3^{* *} \pm 12,5$ & $4,0-64$ & $1,73 \pm 1,02$ & $0,1-6,68$ & $7,95^{* *} \pm 5,99$ & $0,1-36$ \\
\hline \multicolumn{9}{|l|}{ Berulang } \\
\hline F-44 & $1,71^{* *} \pm 0,55$ & $0,57-3,58$ & $36,0^{*} \pm 10,9$ & $11,0-65$ & $1,03^{* *} \pm 0,44$ & $0,16-2,48$ & $3,43^{*} \pm 2,62$ & $0,4-14,35$ \\
\hline K-95 & $2,07^{*} \pm 0,6$ & $0,8-3,28$ & $43,3 \pm 12,8$ & $14-72$ & $1,39 \pm 0,48$ & $0,31-2,47$ & $6,73^{* *} \pm 5,81$ & $0,5-33,47$ \\
\hline WL-711 & $1,91^{* *} \pm 0,59$ & $0,63-3,56$ & $38,5^{* *} \pm 10,7$ & $11,0-68$ & $1,19^{* *} \pm 0,48$ & $0,2-2,34$ & $5,22 \pm 3,8$ & $0,2-18,49$ \\
\hline
\end{tabular}

Keterangan : X: rataan ; Sx : standar deviasi, *: berbeda nyata dengan populasi kontrol pada taraf $5 \%$ berdasarkan uji t; **: berbeda nyata dengan populasi kontrol pada taraf $1 \%$ berdasarkan uji t. 
akut yang biasa digunakan. Penggunaan dosis pada iradiasi akut yang hanya sekali dalam skala besar menimbulkan potensi kerusakan genetik yang lebih besar dibanding iradiasi terbagi [20]. Penggunaan dosis iradiasi awal setengah dari dosis iradiasi akut pada perlakuan iradiasi terbagi dan berulang menyebabkan kerusakan fisik DNA yang lebih kecil, memberikan kemungkinan pemulihan DNA yang lebih cepat [21] dan mengurangi potensi terjadinya delesi besar yang menghilangkan gen-gen mayor pengendali karakter kuantitatif [22]. Adapun iradiasi kedua dengan dosis yang sama (iradiasi terbagi) atau lebih kecil (iradiasi berulang) memberikan kesempatan terjadinya mutasi pada bagian DNA yang lain tanpa mengubah total susunan gen yang sudah ada [23]. Kerusakan genetik yang lebih kecil pada perlakuan iradiasi terbagi dan berulang saat generasi M1 memberikan dampak yang lebih baik pada viabilitas dan vigor tanaman M2.

Kisaran menunjukkan nilai sebaran fenotip yang mengindikasikan terjadinya induksi mutasi mikro dengan meningkatnya keragaman karakter poligenik dalam populasi [15]. Perlakuan teknik iradiasi menginduksi peningkatan rentang kisaran pada semua karakter kuantitatif populasi M2 gandum. Hal ini menggambarkan bahwa induksi mutasi mikro pada karakter agronomi melalui tiga teknik sinar gamma telah berhasil dilakukan. Perlakuan iradiasi terbagi menyebabkan populasi M2 memiliki kisaran terluas pada tiga galur gandum dalam karakter tinggi tanaman, jumlah anakan produktif, panjang malai dan bobot biji per malai. Kisaran karakter bobot biji per tanaman hasil induksi mutasi iradiasi terbagi dan berulang lebih tinggi dibanding iradiasi akut pada galur F44 dan K-95. Semakin banyak gen yang termutasi akan menimbulkan besarnya segregasi yang meningkatkan ragam dalam populasi [24]. Sebagian mutasi menghasilkan karakter yang bermanfaat untuk pemuliaan tanaman atau bersifat positif seperti pertambahan densitas spikelet per malai (compactoid) serta peningkatan panjang malai maupun negatif seperti sterilitas, abnormalitas dan lethalitas [6, 9]. Keduanya menyebabkan peningkatan variasi nilai komponen hasil setiap individu dalam populasi dan memperluas rentang kisaran. Dua kali aplikasi dosis iradiasi pada perlakuan iradiasi terbagi dan berulang berpotensi menginduksi lebih banyak gen yang termutasi. Hal ini memicu peningkatan luasan nilai kisaran karakter komponen hasil perlakuan iradiasi terbagi dan berulang lebih tinggi dibanding perlakuan iradiasi akut.

Penanaman gandum di Indonesia terkendala dengan cekaman suhu tinggi. Gandum yang mengalami cekaman suhu tinggi umumnya mempersingkat periode perkembangan tanaman sehingga menghasilkan organ yang lebih sedikit, ukuran organ yang lebih kecil serta siklus hidup yang lebih pendek [25]. Hasil penelitian Baloch et al. menunjukkan bahwa karakter panjang malai dan jumlah spikelet per malai merupakan karakter yang ekspresinya sedikit dipengaruhi oleh cekaman suhu tinggi [26]. Oleh karena itu, pemuliaan gandum Indonesia diarahkan untuk mendapatkan tanaman dengan kemampuan membentuk lubuk (sink) yang besar misalnya dengan meningkatkan karakter panjang malai dan jumlah spikelet per malai. Pada penelitian ini, peningkatan keragaman genetik panjang malai dan jumlah spikelet dalam populasi gandum dilakukan dengan mengaplikasikan tiga teknik iradiasi. Perlakuan teknik iradiasi yang mampu menginduksi karakter panjang malai dan jumlah spikelet per malai memiliki rataan tinggi dan kisaran yang luas adalah iradiasi terbagi.

Pengujian homogenitas ragam digunakan untuk membandingkan ragam antara dua populasi yang berbeda. Dalam penelitian ini, uji homogenitas ragam digunakan untuk membedakan antar ragam populasi M2 hasil induksi tiga teknik iradiasi pada semua variabel pengamatan. Perbedaan yang nyata antar ragam populasi M2 menunjukkan perbedaan kemampuan setiap teknik iradiasi dalam menginduksi peningkatan ragam dalam populasi. Hasil uji homogenitas ragam antar perlakuan iradiasi dapat dilihat pada Tabel 2.

Iradiasi akut menginduksi ragam yang berbeda dengan perlakuan iradiasi terbagi dan berulang pada karakter bobot biji per tanaman. Teknik iradiasi terbagi dan berulang menghasilkan nilai ragam yang lebih tinggi dibanding teknik iradiasi akut. Hal ini menunjukkan bahwa aplikasi mutagen lebih dari satu kali dapat menginduksi variabilitas genetik lebih baik dari aplikasi mutagen tunggal pada populasi menurut [27], aplikasi mutagen fisik sinar gamma lebih dari sekali pada tomat menghasilkan peningkatan ragam genetik populasi lebih tinggi dibanding mutagen tunggal. Penggunaan mutagen lebih dari satu kali meningkatkan potensi terjadinya mutasi ada bagian DNA yang berbeda sehingga dapat memperbesar ragam genetik populasi [23]. 
Tabel 2. Hasil uji homogenitas ragam karakter agronomi gandum generasi M2 hasil perlakuan tiga teknik iradiasi pada tiga galur gandum

\begin{tabular}{lllllllll}
\hline \multirow{2}{*}{ Perlakuan } & \multicolumn{7}{c}{ Karakter } \\
\cline { 2 - 8 } & TT & JAP & PM & JSP & BM & JBM & BBM & BBT \\
\hline Akut vs Terbagi & 1,10 & $1,93^{* *}$ & 1,05 & $1,56^{*}$ & 1,27 & 1,36 & 1,06 & $2,08^{* *}$ \\
F-44 & 1,22 & $1,02^{*}$ & 1,19 & 1,23 & 1,32 & 1,16 & 1,50 & $2,03^{* *}$ \\
Kiran-95 & $1,53^{*}$ & $1,52^{*}$ & 1,03 & $1,92^{* *}$ & 1,07 & 1,33 & $5,66^{* *}$ & $1,93^{* *}$ \\
WL-711 & $1,44^{*}$ & $1,49^{*}$ & $1,76^{* *}$ & 1,29 & 1,22 & $1,46^{*}$ & $1,54^{*}$ & $3,19^{* *}$ \\
Akut vs Berulang & 1,06 & $1,31^{* *}$ & 1,11 & 1,00 & 1,15 & 1,37 & $1,15^{* *}$ & $2,05^{* *}$ \\
F-44 & 1,27 & $3,61^{* *}$ & 1,01 & $1,06^{* *}$ & $1,40^{*}$ & 1,20 & $1,80^{* *}$ & $3,92^{* *}$ \\
Kiran-95 & 1,31 & 1,29 & $1,68^{* *}$ & 1,20 & $1,54^{*}$ & 1,07 & $1,63^{* *}$ & $1,54^{*}$ \\
WL-711 & 1,06 & 1,29 & 1,32 & 1,22 & $1,52^{*}$ & $1,59^{*}$ & 1,72 & 1,01 \\
Terbagi vs Berulang & 1,20 & $5,49^{* *}$ & 1,02 & $2,05^{* *}$ & $1,49^{*}$ & 1,11 & $10,18^{* *}$ & $7,57^{* *}$ \\
F-44 & &
\end{tabular}

Keterangan : TT: tinggi tanaman (cm); JAP: jumlah anakan produktif; PM: panjang malai (cm); JSP: jumlah spikelet tiap malai; BM: bobot malai (g); JBM: jumlah biji per malai; BBM: bobot biji per malai (g); BBT: bobot biji per tanaman; *: terdapat beda nyata pada taraf $5 \%$ berdasarkan uji $\mathrm{F} ;{ }^{* *}$ : terdapat beda nyata pada taraf $1 \%$ berdasarkan uji $\mathrm{F}$.

Perakitan variaetas unggul berproduksi tinggi memerlukan informasi tentang ragam genetik hasil dan komponennya dalam populasi yang dimuliakan. Nilai ragam genetik dan lingkungan menentukan besarnya heritabilitas, koefisien ragam fenotipik dan genetik karakter komponen hasil [28]. Parameter tersebut penting untuk digunakan dalam menentukan kriteria seleksi [29]. Ragam fenotip, ragam genetik, heritabilitas dalam arti luas dan nilai koefisien variasi genetik populasi M2 hasil induksi tiga teknik iradiasi sinar gamma pada tiga galur gandum dapat dilihat pada Tabel 3 .

Perlakuan iradiasi akut memicu populasi M2 memiliki karakter agronomi dengan heritabilitas tinggi kecuali jumlah spikelet per malai. Iradiasi terbagi pada galur F-44 menghasilkan karakter tinggi tanaman, jumlah anakan produktif, bobot malai, bobot biji per malai dan bobot biji per tanaman yang memiliki heritabilitas tinggi pada populasi M2. Iradiasi terbagi pada galur K-95 menginduksi terbentuknya populasi M2 yang memiliki heritabilitas tinggi pada seluruh karakter agronomi kecuali panjang malai sedangkan iradiasi terbagi pada galur WL-711 menginduksi populasi M2 memiliki semua karakter dengan heritabilitas tinggi kecuali tinggi tanaman. Iradiasi berulang pada galur F-44 mempengaruhi keragaman dalam populasi M2 membentuk karakter jumlah anakan produktif, bobot malai, bobot biji per malai dan bobot biji per tanaman yang memiliki heritabilitas tinggi. Iradiasi berulang menghasilkan semua karakter agronomi pada populasi M2 galur K-95 memiliki heritabilitas tinggi. Iradiasi berulang pada galur WL-711 menginduksi populasi M2 memiliki heritabilitas bernilai tinggi pada seluruh karakter agronomi kecuali tinggi tanaman.

Karakter agronomi jumlah anakan produktif, bobot biji per malai dan bobot biji per tanaman pada populasi M2 hasil induksi mutasi tiga teknik iradiasi gamma terhadap tiga galur gandum menunjukkan heritabilitas tinggi. Hal ini senada dengan penelitian induksi mutasi pada gandum $[11,30]$ yang mendapatkan karakter jumlah anakan, bobot biji per malai dan bobot biji per tanaman yang juga memiliki heritabilitas tinggi. Heritabilitas tinggi suatu karakter mengindikasikan bahwa pengaruh faktor genetik lebih besar dibanding faktor lingkungan. Tingginya heritabilitas mencerminkan banyaknya gen aditif yang berkontribusi pada sifat tersebut sehingga dapat diwariskan pada generasi berikutnya [31]. Heritabilitas tinggi pada karakter yang diinduksi dengan iradiasi akut menunjukkan bahwa variasi fenotipik yang muncul lebih banyak dipengaruhi oleh besarnya varian genetik akibat mutasi. Sebagian karakter yang diinduksi dengan iradiasi terbagi dan berulang memiliki heritabilitas yang sedang atau rendah memperlihatkan bahwa 
Tabel 3. Komponen ragam dan koefisien keragaman genetik karakter tinggi tanaman $(\mathrm{cm})$, jumlah anakan produktif, panjang malaI, jumlah spikelet per malai, bobot malai, jumlah biji per malai, bobot biji per malai dan bobot biji per tanaman gandum generasi M2

\begin{tabular}{|c|c|c|c|c|c|c|c|c|c|}
\hline \multirow{3}{*}{$\begin{array}{c}\text { Komponen } \\
\text { Ragam }\end{array}$} & \multicolumn{9}{|c|}{ Perlakuan } \\
\hline & \multicolumn{3}{|c|}{ Akut } & \multicolumn{3}{|c|}{ Terbagi } & \multicolumn{3}{|c|}{ Berulang } \\
\hline & F-44 & K-95 & WL-711 & $\mathrm{F}-44$ & $\mathrm{~K}-95$ & WL-711 & $\mathrm{F}-44$ & $\mathrm{~K}-95$ & WL-711 \\
\hline & \multicolumn{9}{|c|}{ Tinggi tanaman $(\mathrm{cm})$} \\
\hline$\sigma^{2} \mathrm{p}$ & 53 & 80,3 & 90,9 & 48,2 & 98,2 & 59,4 & 36,9 & 92,4 & 71,4 \\
\hline$\sigma^{2} \mathrm{~g}$ & 30,9 & 41,8 & 52,1 & 26,1 & 59,6 & 20,5 & 14,8 & 53,9 & 32,5 \\
\hline $2 \sigma_{\sigma 2 \mathrm{q}}$ & 11.12 & 12.93 & 14.43 & 10.22 & 15.45 & 9.06 & 7.69 & 14.68 & 11.41 \\
\hline $\mathrm{h}_{\mathrm{bs}}^{2}$ & $0,58^{\mathrm{T}}$ & $0,52^{\mathrm{T}}$ & $0,57^{\mathrm{T}}$ & $0,54^{\mathrm{T}}$ & $0,61^{\mathrm{T}}$ & $0,35^{\mathrm{Sd}}$ & $0,40^{\mathrm{Sd}}$ & $0,58^{\mathrm{T}}$ & $0,46^{\mathrm{Sd}}$ \\
\hline \multirow[t]{2}{*}{ KKG } & $13,1^{\mathrm{L}}$ & $13,9^{\mathrm{L}}$ & $12,8^{\mathrm{S}}$ & $11,2^{\mathrm{L}}$ & $16,1^{\mathrm{L}}$ & $7,5^{\mathrm{s}}$ & $8,8^{\mathrm{L}}$ & $12,9^{\mathrm{S}}$ & $10,2^{\mathrm{S}}$ \\
\hline & \multicolumn{9}{|c|}{ Jumlah Anakan Produktif } \\
\hline$\sigma^{2} \mathrm{p}$ & 2,3 & 12,4 & 19,8 & 4,5 & 12,7 & 30,2 & 3,5 & 16,3 & 5,5 \\
\hline$\sigma^{2} \mathrm{~g}$ & 1,8 & 11 & 17,9 & 4 & 11,2 & 28,2 & 3 & 14,8 & 3,5 \\
\hline $2 \sigma_{\sigma 2 \mathrm{~g}}$ & 2.72 & 6.64 & 8.46 & 4.01 & 6.7 & 10.62 & 3.47 & 7.71 & 3.76 \\
\hline $\mathrm{h}_{\mathrm{bs}}^{2}$ & $0,79^{\mathrm{T}}$ & $0,88^{\mathrm{T}}$ & $0,90^{\mathrm{T}}$ & $0,89^{\mathrm{T}}$ & $0,89^{\mathrm{T}}$ & $0,94^{\mathrm{T}}$ & $0,86^{\mathrm{T}}$ & $0,91^{\mathrm{T}}$ & $0,64^{\mathrm{T}}$ \\
\hline \multirow[t]{2}{*}{ KKG } & $49,9^{\mathrm{L}}$ & $67,3^{\mathrm{L}}$ & $57,4^{\mathrm{L}}$ & $60,1^{\mathrm{L}}$ & $70,7^{\mathrm{L}}$ & $67,9^{\mathrm{L}}$ & $49,9^{\mathrm{L}}$ & $63,0^{\mathrm{L}}$ & $33,3^{\mathrm{L}}$ \\
\hline & \multicolumn{9}{|c|}{ Panjang malai $(\mathrm{cm})$} \\
\hline$\sigma^{2} \mathrm{p}$ & 1,54 & 1,8 & 1,33 & 1,46 & 1,52 & 1,29 & 0,87 & 2 & 1,31 \\
\hline$\sigma^{2} \mathrm{~g}$ & 0,77 & 0,93 & 0,84 & 0,7 & 0,64 & 0,8 & 0,11 & 1,13 & 0,82 \\
\hline $2 \sigma_{\sigma 2 \mathrm{~g}}$ & 1.76 & 1.93 & 1.83 & 1.67 & 1.61 & 1.79 & 0.66 & 2.12 & 1.82 \\
\hline $\mathrm{h}_{\mathrm{bs}}^{2}$ & $0,50^{\mathrm{T}}$ & $0,51^{\mathrm{T}}$ & $0,63^{\mathrm{T}}$ & $0,48^{\mathrm{Sd}}$ & $0,42^{\mathrm{Sd}}$ & $0,62^{\mathrm{T}}$ & $0,12^{\mathrm{R}}$ & $0,56^{\mathrm{T}}$ & $0,63^{\mathrm{T}}$ \\
\hline \multirow[t]{2}{*}{$\mathrm{KKG}$} & $13,3^{\mathrm{L}}$ & $13,6^{\mathrm{L}}$ & $11,3^{\mathrm{L}}$ & $11,6^{\mathrm{L}}$ & $11,4^{\mathrm{L}}$ & $10,3^{\mathrm{L}}$ & $4,8^{\mathrm{L}}$ & $13,8^{\mathrm{L}}$ & $11,7^{\mathrm{L}}$ \\
\hline & \multicolumn{9}{|c|}{ Jumlah spikelet per malai } \\
\hline$\sigma^{2} \mathrm{p}$ & 7,62 & 7,24 & 6,17 & 4,9 & 8,89 & 3,21 & 0,87 & 7,26 & 6,56 \\
\hline$\sigma^{2} g$ & 3,44 & 5,02 & 5,27 & 0,72 & 6,67 & 2,31 & 0,11 & 5,04 & 5,66 \\
\hline $2 \sigma_{\sigma 2 \mathrm{q}}$ & 3.71 & 4.48 & 4.59 & 1.69 & 5.17 & 3.04 & 2.62 & 4.49 & 4.76 \\
\hline $\mathrm{h}_{\mathrm{bs}}^{2}$ & $0,45^{\mathrm{Sd}}$ & $0,69^{\mathrm{T}}$ & $0,85^{\mathrm{T}}$ & $0,15^{\mathrm{R}}$ & $0,75^{\mathrm{T}}$ & $0,72^{\mathrm{T}}$ & $0,12^{\mathrm{R}}$ & $0,69^{\mathrm{T}}$ & $0,86^{\mathrm{T}}$ \\
\hline \multirow[t]{2}{*}{ KKG } & $13,6^{\mathrm{L}}$ & $15,0^{\mathrm{L}}$ & $17,1^{\mathrm{L}}$ & $5,5^{\mathrm{L}}$ & $18,6^{\mathrm{L}}$ & $10,0^{\mathrm{L}}$ & $4,8^{\mathrm{L}}$ & $14,9^{\mathrm{L}}$ & $16,8^{\mathrm{L}}$ \\
\hline & \multicolumn{9}{|c|}{ Bobot malai (g) } \\
\hline$\sigma^{2} \mathrm{p}$ & 0,37 & 0,45 & 0,39 & 0,47 & 0,59 & 0,41 & 0,31 & 0,39 & 0,28 \\
\hline$\sigma^{2} \mathrm{~g}$ & 0,22 & 0,36 & 0,3 & 0,32 & 0,5 & 0,33 & 0,15 & 0,3 & 0,19 \\
\hline $2 \sigma_{\sigma 2 \mathrm{q}}$ & 0.94 & 1.2 & 1.1 & 1.13 & 1.42 & 1.14 & 0.78 & 1.09 & 0.87 \\
\hline $\mathrm{h}_{\mathrm{bs}}^{2}$ & $0,59^{\mathrm{T}}$ & $0,80^{\mathrm{T}}$ & $0,78^{\mathrm{T}}$ & $0,67^{\mathrm{T}}$ & $0,85^{\mathrm{T}}$ & $0,79^{\mathrm{T}}$ & $0,50^{\mathrm{T}}$ & $0,77^{\mathrm{T}}$ & $0,69^{\mathrm{T}}$ \\
\hline \multirow[t]{2}{*}{ KKG } & $31,4^{\mathrm{L}}$ & $30,9^{\mathrm{L}}$ & $29,0^{\mathrm{L}}$ & $28,2^{\mathrm{L}}$ & $38,9^{\mathrm{L}}$ & $26,4^{\mathrm{L}}$ & $22,8^{\mathrm{L}}$ & $26,5^{\mathrm{L}}$ & $22,8^{\mathrm{L}}$ \\
\hline & \multicolumn{9}{|c|}{ Jumlah biji per malai } \\
\hline$\sigma^{2} \mathrm{p}$ & 172 & 218,7 & 142,5 & 126,5 & 253,7 & 107,5 & 118 & 159,8 & 119,1 \\
\hline$\sigma^{2} \mathrm{~g}$ & 100 & 174,7 & 99,8 & 54,5 & 209,7 & 64,8 & 46 & 115,7 & 76,3 \\
\hline $2 \sigma_{\sigma 2 \mathrm{~g}}$ & 20 & 26.44 & 19.98 & 14.76 & 28.96 & 16.1 & 13.57 & 21.52 & 17.47 \\
\hline $\mathrm{h}_{\mathrm{bs}}^{2}$ & $0,58^{\mathrm{T}}$ & $0,80^{\mathrm{T}}$ & $0,70^{\mathrm{T}}$ & $0,43^{\mathrm{Sd}}$ & $0,83^{\mathrm{T}}$ & $0,60^{\mathrm{T}}$ & $0,39^{\mathrm{Sd}}$ & $0,72^{\mathrm{T}}$ & $0,64^{\mathrm{T}}$ \\
\hline \multirow[t]{2}{*}{ KKG } & $34,23^{\mathrm{L}}$ & $34,62^{\mathrm{L}}$ & $25,54^{\mathrm{L}}$ & $17,97^{\mathrm{L}}$ & $39,49^{\mathrm{L}}$ & $19,47^{\mathrm{L}}$ & $18,82^{\mathrm{L}}$ & $24,84^{\mathrm{L}}$ & $22,69^{\mathrm{L}}$ \\
\hline & \multicolumn{9}{|c|}{ Bobot biji per malai (g) } \\
\hline$\sigma^{2} \mathrm{p}$ & 0,29 & 0,29 & 0,28 & 0,31 & 0,43 & 1,57 & 0,19 & 0,25 & 0,15 \\
\hline$\sigma^{2} \mathrm{~g}$ & 0,2 & 0,25 & 0,21 & 0,21 & 0,4 & 1,5 & 0,09 & 0,21 & 0,09 \\
\hline $2 \sigma_{\sigma 2 \mathrm{~g}}$ & 0.89 & 1 & 0.92 & 0.93 & 1.26 & & 0.62 & & 0.59 \\
\hline $\mathrm{h}_{\mathrm{bs}}^{2}$ & $0,67^{\mathrm{T}}$ & $0,88^{\mathrm{T}}$ & $0,76^{\mathrm{T}}$ & $0,69^{\mathrm{T}}$ & $0,92^{\mathrm{T}}$ & $0,96^{\mathrm{T}}$ & $0,50^{\mathrm{T}}$ & $0,86^{\mathrm{T}}$ & $0,56^{\mathrm{T}}$ \\
\hline \multirow[t]{2}{*}{$\mathrm{KKG}$} & $50,9^{\mathrm{L}}$ & $40,6^{\mathrm{L}}$ & $35,4^{\mathrm{L}}$ & $36,9^{\mathrm{L}}$ & $55,9^{\mathrm{L}}$ & $70,7^{\mathrm{L}}$ & $30,0^{\mathrm{L}}$ & $33,4^{\mathrm{L}}$ & $24,7^{\mathrm{L}}$ \\
\hline & & & & Bobot & iji per ta & $\operatorname{aman}(g)$ & & & \\
\hline$\sigma^{2} \mathrm{p}$ & 2,15 & 15,63 & 23,45 & 4,46 & 31,72 & 45,22 & 6,86 & 32,06 & 5,98 \\
\hline$\sigma^{2} \mathrm{~g}$ & 1,25 & 13,53 & 22,18 & 3,57 & 29,61 & 43,95 & 5,96 & 29,95 & 4,7 \\
\hline & & & & & 10.88 & 13.26 & 4.88 & 10.95 & 4.34 \\
\hline $\mathrm{h}_{\mathrm{bs}}^{2}$ & $0,58^{\mathrm{T}}$ & $0,87^{\mathrm{T}}$ & $0,95^{\mathrm{T}}$ & $0,80^{\mathrm{T}}$ & $0,93^{\mathrm{T}}$ & $0,97^{\mathrm{T}}$ & $0,87^{\mathrm{T}}$ & $0,93^{\mathrm{T}}$ & $0,79^{\mathrm{T}}$ \\
\hline KKG & $56,9^{\mathrm{L}}$ & $79,8^{\mathrm{L}}$ & $76,0^{\mathrm{L}}$ & $56,3^{\mathrm{L}}$ & $126,3^{\mathrm{L}}$ & $83,4^{\mathrm{L}}$ & $71,3^{\mathrm{L}}$ & $81,3^{\mathrm{L}}$ & $41,5^{\mathrm{L}}$ \\
\hline
\end{tabular}

pengaruh genetik akibat induksi mutasi lebih kecil dibanding pengaruh lingkungan.
Semua teknik iradiasi yang diaplikasikan mampu menginduksi keragaman genetik yang luas 
pada semua karakter agronomi populasi M2 kecuali tinggi tanaman. Nilai keragaman genetik populasi pada generasi M2 lebih luas dibanding ragam genetik generasi M3 [11] dan M5 [30] karena seleksi belum diaplikasikan pada generasi ini. Keragaman yang tinggi dapat pada populasi mempermudah proses seleksi untuk mendapatkan ideotipe tanaman yang diharapkan $[23,29]$. Adanya nilai keragaman genetik dan heritabilitas yang tinggi pada karakter tertentu saat generasi M2 memungkinkan dimulainya seleksi pada generasi tersebut. Induksi mutasi melalui iradiasi sinar gamma pada penelitian ini terbukti efektif meningkatkan ragam genetik karakter hasil pada populasi gandum. Hal serupa diperoleh pada penelitian Al Naggar et al. bahwa induksi mutasi mampu meningkatkan ragam genetik karakter jumlah anakan produktif dan hasil per tanaman [32]. Induksi mutasi dengan iradiasi terbagi dan berulang dapat digunakan dalam pemuliaan gandum tropis karena mampu memperluas keragaman genetik sink (panjang malai dan jumlah spikelet per malai) dan karakter hasil pada populasi M2. Keragaman genetik yang luas pada karakter panjang malai dan jumlah spikelet memberikan peluang yang lebih besar bagi pemulia untuk melakukan perbaikan karakter tersebut melalui seleksi.

\section{KESIMPULAN}

1. Teknik iradiasi terbagi mampu menginduksi nilai rataan yang lebih tinggi dengan kisaran yang lebih luas pada karakter panjang malai dan jumlah spikelet per malai dibanding teknik iradiasi yang lain.

2. Teknik iradiasi terbagi dan berulang menghasilkan ragam yang lebih besar dibanding iradiasi akut pada karakter hasil biji per tanaman pada populasi M2.

3. Karakter agronomi jumlah anakan produktif, bobot malai, bobot biji per malai dan bobot biji per tanaman pada populasi M2 hasil induksi tiga teknik iradiasi memiliki heritabilitas yang tinggi.

4. Tiga teknik iradiasi menginduksi perluasan keragaman genetik semua karakter agronomi populasi M2 yang diamati, kecuali tinggi tanaman.

\section{UCAPAN TERIMA KASIH}

Penulis menyampaikan terima kasih kepada Kementerian Riset dan Pendidikan Tinggi yang telah memberikan beasiswa dan mendanai penelitian tahun 2014, Balai Besar Penelitian dan Pengembangan Bioteknologi dan Sumber Daya Genetik Pertanian, Kementerian Pertanian yang telah menyediakan lahan dan kepada Bapak Sihono SP, Sujarno SP, Haerul Hartono serta Petugas Lapangan Bidang Pertanian PAIRBATAN yang telah membantu teknis penelitian

\section{DAFTAR PUSTAKA}

1. Setyowati, M., Hanarida I., Sutoro, Pengelompokan plasma nutfah gandum (Triticum aestivum L.) berdasarkan karakter kuantitatif tanaman, Buletin Plasma Nutfah, 15, 1, 32-37, 2009.

2. Nur, A., Azrai, M., Subagio, H., Human, S., Trikoesoemaningtyas, Perkembangan pemuliaan gandum di Indonesia, Iptek Tanaman Pangan, 8, 2, 97-105, 2013.

3. Albokari, M.M.A., Induction of mutants in durum wheat (Triticum durum Desf. $\mathrm{Cv}$ Samra) using gamma irradiation, Pak. $J$. Bot., 46, 1, 317-324, 2014.

4. Asadi, Pemuliaan mutasi untuk perbaikan terhadap umur dan produktivitas pada kedelai, Jurnal Agro Biogen, 9, 3, 135$142,2013$.

5. Foster, B.P., Shu, Q.Y., Plant mutagenesis in crop improvement: basic terms and applications, in: Shu, Q.Y., Foster, B.P., Nakagawa, H., editor, Plant Mutation Breeding and Biotechnology, London, CAB International dan FAO, 2012.

6. Mishra, D., Singh, B., Prediction of M2 macro and micro-mutation frequency based on M1 effect in greengram [Vigna radiata (L.) Wilczek], IOSR Journal of Agriculture and Veterinary Science, 2, 1, 1-4, 2013.

7. Piluek, C., Wongpiyasatid, A., Achievement Sub-Project on Insect Resistance in 
Orchid (2003 - 2009), Mutation Breeding Project. Thailand, Forum for Nuclear Cooperation in Asia (FNCA), 2010.

8. Kodym, A., Azfa, R., Foster, B.P., Ukai, Y., Nakagawa, H., Mba, C., Methodology for physical and chemical mutagenic treatments, in: Shu, Q.Y., Foster, B.P., Nakagawa, H., editor. Plant Mutation Breeding and Biotechnology. London (GB): CAB International dan FAO, 2012.

9. Banerjee, S.K., Maximization of the induced mutation frequency in wheat by radiations, Proc Indian Ac Ad Sci Sect B, 1-21, 1966.

10. Aisyah, S.I., Induksi mutagen fisik pada anyelir (Dianthus caryopphyllus L.) dan pengujian stabilitas mutannya yang diperbanyak secara vegetative, Disertasi, Institut Pertanian Bogor, 2006.

11. Nur, A, Human, S., Trikosoemaningtyas. Keragaman genetik gandum populasi mutan M3diagroekosistem tropis, Jurnal Aplikasi Isotop dan Radiasi, 10, 1, 35 44, 2014.

12. Asghar, M.J., Mehdi, S.S., Selection indices for yield and quality traits of sweet corn, Pak J Bot., 42, 775-789, 2010.

13. Begum, T., Dasgupta, T., Induced genetic variability, heritability and genetic advance in sesame (Sesamum indicum L.), Sabrao Journal of Breeding and Genetics, 46, 1, 21-33, 2014.

14. Sakin, M.A., The use of induced micromutation for quantitative characters after EMS and gamma ray treatments in durum wheat breeding, Pakistan Journal of Applied Sciences2, 12, 1102-1107, 2002.

15. Borojevic, K., Studies on radiation-induced mutation in quantitative characters of wheat (Triticum vulgare). In Mutation on Plant Breeding, Proceeding of panel coordination research on production and induced mutation in plant breeding; $17-$ 21 January 1966; Vienna, Austria. Vienna (AT): Joint Joint Food and Agriculture Organization (FAO)/ International Atomic Energy Agency (IAEA), 1966.

16. Oliveira, F.A.D., Viccini, L.F., Induction of maize chromosome altered plants by seeds irradiation pre-soaked in metronidazole, Caryologia, 57, 1, 79-87, DOI:10.1080/00087114.2004.10589375, 2004.

17. Hanafiah, D.S., Trikoesoemaningtyas, Yahya, S., Wirnas, D., Induced mutations by gamma ray irradiation to Argomulyo soybean (Glycine max) variety. Nusantara Bioscience, 2, 3, 121-125, 2010.

18. Han, B., Gu J., Zhao, L., Guo, H., Xie, Y., Zhao, S., Song, X., Han L., Liu, L., Factors Affecting the Radiosensitivity of Hexaploid Wheat to -Irradiation: Radiosensitivity of Hexaploid Wheat (Triticum aestivum L.). Plos One, 11, 8, e0161700. doi: 10.1371/ journal.pone.0161700, 2016.

19. Kumar, A., Simon, K., Iqbal, J., Jimenez, M.M.D., Bassi, F.M., Ghvami, F., AlAzam, O., Drader, T., Wang, Y., Luo, M.C., Gu, Y.Q., Denton, A., Lazo, G.R., $\mathrm{Xu}$, S.S., Dvorak, J., Kianian, P.M.A., Kianian, S.F., Physical mapping resources for large plant genome: radiation hybrids for wheat $\mathrm{D}$-genomes progenitor Aegilops tauschii. $B M C$ Genomics, 13, 597, 2012.

20. Ojima, M., Ito, M., Suzuki, K., Kai, M., Unstable Chromosome Aberrations Do Not Accumulate in Normal Human Fibroblast after Fractionated XIrradiation. Plos One, 10, 2, e0116645. doi:10.1371/journal.pone.0116645, 2015.

21. Vignard, J., Mirey, G., Salles, B., Ionizingradiation induced DNA double-strand breaks: A direct and indirect lighting up. 
Radiotherapy and Oncology J., 108, 362-369, 2013.

22. Morita, R., Kusaba, M., Iida, S., Yamaguchi, H., Nishio, T., Nishimura, M., Molecular characterization of mutations induced by gamma irradiation in rice. Genes Genet. Syst., 84, 361-370, 2009.

23. Ukai, Y., Theoretical studies on population development design in mutation breeding of allogamous plants, Breeding Science, 60, 267-278, 2010.

24. Sakin, M.A., Yildrim, A., Gokmen, S., The evaluation of agronomic traits of durum wheat (Triticum durum Desf.) Mutants. Pak J. Biol Sci., 7, 4, 571-576, 2004.

25. Maestri, E., Klueva, N., Perrota, C., Gulli, M., Nguyen, H.T., Marmiroli N., Molecular genetics of heat tolorance and heat shock proteins in cereals, Plant Mol Bio, 48, 667-681, 2002.

26. Baloch, M., Baloch, A.W., Shaikh, Z.A., Arain, S., Baloch, M.J., Asad, M.A., Baloch, G.M., Ali, M., Baloch, A.M., Assessment of elite wheat genotypes for heat stress on the basis of yield contributing traits, Int. J. Biotech., 13, 1, 101-106, 2016.

27. Nunoo, J., Quartey, E.K., Amoatey, H.M., Klu, G.Y.P., Effect of recurrent irradiation on the improvement of a variant line of wild tomato (Solanum pimpinellifolium). Journal of Radiation Research and Applied Sciences, 7, 377383, 2014.
28. Wani, M.R., Khan, S., Estimates of genetic variability in mutated populations and the scope of selection for yield attributes in Vigna radiata (L.) Wilczek. Egypt $J$. Biol., 8, 1-6, 2006.

29. Indriatama, W.M., Sihono, Puspitasari, W., Human, S., Evaluasi fenotipik, heritabilitas dan variabilitas genetik komponen hasil galur-galur mutan gandum (Triticum aestivum L.). Prosiding Seminar dan Pameran Aplikasi Teknologi Isotop dan Radiasi, 335-348, 2013.

30. Febrianto, E.B., Wahyu, Y., Wirnas, D., Keragaan dan keragaman genetik karakter agronomi galur mutan putatif gandum generasi M5. J. Agron. Indonesia, 43, 1, 52-58, 2015.

31. Jambormias, E., Sutjahjo, S.H., Jusuf, M., Suharsono. Keragaman genetik dan heritabilitas 11 sifat kuantitatif kedelai (Glycine $\max$ L. Merrill) pada generasi seleksi $\mathrm{F} 5$ persilangan varietas Slamet $\mathrm{x}$ Nakhonsawan. J. Pertanian Kepulauan, 3, 2, 115-124, 2004.

32. Al-Naggar, A.M.M., Al-Azab, K.H.F., Sobieh, S.E.S.E., Atta, M.M.M., Variation induction in wheat via gammarays and hybridization and gains from selection in derived heterogeneous populations for drought tolerance. Sci. Agri., 9, 1, 1-15, 2015. 